\title{
CLIMATE CHANGE-FOOD SECURITY-FINANCIAL ASSETS NEXUS: EVIDENCE FROM INDONESIA

\author{
${ }_{1,2,3,4}$ Doctoral Program, Faculty of Economics and Business, SebelasMaret University, Indonesia \\ Email:*dini.yuniarti@uad.ac.id
} \\ ${ }^{1 *}$ Dini Yuniarti, ${ }^{2}$ Yunastiti Purwaningsih, ${ }^{3} \mathrm{AM}$ Soesilo, ${ }^{4}$ Agustinus Suryantoro
}

Article History: Received on $02^{\text {nd }}$ January, Revised on $30^{\text {th }}$ March, Published on $15^{\text {th }}$ April 2019

\begin{abstract}
Purpose: The aim of the study is to investigate the position of household food security when they face climate change and examine the influence of financial asset on food security dynamic. Additionally, we investigate the impact of livelihood assets such as human capital, financial capital, social capital, natural capital, and physical capital on food security dynamic.
\end{abstract}

Methodology: There are four categories of food security dynamic namely household that always secure, improved, worse, and always food insecure. Taking the case on Kulonprogo, Yogyakarta Special Region, we use primary data with a longitudinal survey when El Nino (2015) and La Nina (2016). The sample size is 107 households of Program KeluargaHarapan's receiver. To examine the association between financial assets and food security dynamic we used Multinomial Logit Regression.

Results: The results of the study indicates that households in the face of climate change did not experience significant changes in food security positions in both seasons (El Nińo and La Nińa). Mild food insecurity still dominates impoverished households.

Implications: Thus, the proportion of households that experienced improvement or decline was dominated by mild food insecurity. Furthermore, financial assets such as saving and credit can enhance poor household food security. Meanwhile, there are not all household livelihood assets improve food security yet; only human capital and natural capital can improve household food security. The appropriate food security strategies can be the focus on financial sector intervention program.

\section{Keywords: Climate Change, Financial Asset, Food Security, Household livelihood assets, El Nińo and La Nińa INTRODUCTION}

Climate change is one of the factors that influence food security. It is due to climate change causing pressure on the all of food system such as availability, access and utilization (Gregory, Ingram, \&Brklacich, 2005). Furthermore, Gitz et al. (2016) states that climate change is one of the drivers of poverty and food insecurity. The existence of climate change will increase the poor population between 35 to 122 million in 2030 compared to the future without climate change. Also, the World Bank estimates that without efforts to deal with climate change, extreme air will encourage crop loss by $5 \%$ by 2030, which will increase food prices (Economist Intelligence Unit, 2012). The impacts of climate change affect global food balance, both demand and supply, and local food systems where smallholder communities depend on domestic production (Wheeler \& von Braun, 2013).

Climate change can be in the form of El Niño and La Niña, marked by an increase in sea surface temperature in the Pacific Ocean around the equator. This phenomenon threatens food production due to a decrease in rainfall and long droughts in several regions, one of which is in Indonesia. Another phenomenon is La Niña which often follows the El Niño, which is the cooling of sea level surfaces in the tropical Pacific. For the case of Indonesia, variability and climate change have exacerbated the risk of disasters in Indonesia today. For four decades, floods, droughts, storms, landslides and forest fires have become the biggest threats to livelihoods, economic growth and environmental sustainability (The World Bank Group, 2011)

Indonesia is a priority country for FAO concerning the impacts of El Niño, namely the occurrence of drought, forest fires and cyclones. The effects of El Niño in the form drought phenomena result in a harvest that is not optimal. It causes losses for both farmers and consumers. Farmers will suffer the loss of income from the harvest, while consumer face food price increases. This condition will affect household food security. Because of climate change in the form of El Nino to La Niña has potential to cause household food security dynamics. So, household in both seasons can experience changes are improvement or decline. Therefore, it is essential to know the position of food security during the El Niño and La Niña phenomena.Climate change is a challenge for food security, so we need some effort to cope that. The adaptation of the food system will improve food security for the poor and vulnerable to prepare themselves to face the negative effects of climate change. It requires wider attention not only on the issue of agricultural production (Ziervogel\&Ericksen, 2010). Besides, Wheeler and von Braun (2013) states that the estimation of the food security dimensions includes many longterm, not short-term trends. Whereas the estimate of short food security dimensions can show essential consequences of climate variability in a given year.

For this reason, it is necessary to conduct a study on the determinants of food security, especially in the face of climate change in the short term. Moreover, according to Misselhorn (2005), food security is a multidimensional concept. Five factors cause food insecurity, namely economic, socio-political, scientific and technological, cultural and religious, 
physical, biological, chemical, and demographics. One economic factor that consistently affects food security is financial assets which can be income, savings or credits.

According to Chang et al. (2014) theoretically and empirically shows that the financial capacity of households to borrow and save provides the possibility of a security buffer from food insecurity. It supported by studies stating that financial assets in the form of credits (Asenso-Okyere, Mekonnen, \&Zerfu, 2013), access to security (Dzanja, Christie, Fazey, \& $\underline{\text { Hyde, 2013) }}$ and savings ownership (Guo, 2011) affect food security. For income supported by the study of Akinboade et al. (2016), Sekhampu et al. (2013), Guo (2011), Radha and Prasanna (2010), Butt and Iram (2004), Li and Yu (2010), Martin et al. (2004), Muche and Tadele (2015), Osayande and Ada-Okungbowa (2014), and Shahid and Siddiqi (2010).

But studies linking climate change, food security and financial assets are still limited. Demeke et al. (2011) examined the effect of rainfall and financial capital in Ethiopia on food security. The results show security, savings groups, has no impact on food insecurity. The rainfall and variability are influential. Therefore, this study intends to examine the effect of financial assets on the dynamics of food security between times when climate change occurs. In addition to financial assets will also be reviewed other assets that incorporated in livelihood assets, namely human capital, physical capital, natural capital and social capital.

The Sustainable Livelihood Framework approach provides a framework for the influence of assets on food security. The higher a person's access or ownership to social capital, financial capital, human capital, physical capital, natural resource capital, then one will be more empowered to improve the ability to compile strata e sustainable life. Assets owned by the poor will increase the capacity of the poor to survive shock or vulnerability, one of which is climate change.

\section{METHOD}

Research conducted in Banjararum, Banjarasri, Banjarharjo and Banjaroyo Villages in Kalibawang District. According to Rachman (2004), the fourth one has dynamic food security. It has seen from the condition of food security until 2012 which is all of villages showed food insecure. But, in 2014 all villages had achieved food security (KulonProgo Regency Regional Government, 2016).

Data collected was carried out at two time points, namely the longitudinal data type. Data collection conducted in November 2015 and December 2016. Data collection in November 2015 to obtain data during a long dry season as a result of the El Niño phenomenon, while data collection in December 2016 to obtain events as a result of the impact of La Niña.

The unit of analysis in the study was women from impoverished households. Respondents selected were women, because according to Maxwell and Caldwell (2008) people who prepare food were women. Also it plays a role in improving the family nutrition profile (Smith, 1997). Women are also producers, resource managers, recipients of income, household food managers and food security (Quisumbing\&Meinzen-Dick, 2001) Therefore, according to Sharaunga et al. (2016) women have the potential to reduce the vulnerability of food insecurity, if women get empowerment.

The selection of the household analysis unit based on Wheeler and von Braun (2013) which states that the estimation of the food security dimensions comes more from aggregate data than households or individuals. Therefore, it is necessary to estimate at the household level. The selection of impoverished families because the poor are considered to have a higher level of food insecurity related to the ability to buy food commodities (Sekhampu, 2013), besides poverty is also a driving factor for food insecurity (Misselhorn, 2005). Respondents who meet these two criteria are households who are beneficiaries of the Family Hope Program (PKH). The complete number of samples in two seasons, and has fulfilled missing value test and outliers is 107 households.

The dependent variable is the dynamics of food security between times obtained through three stages. First, calculating the Coping Strategies Index (CSI) food security indicators. Changes in CSI scores indicate changes in the status of food security whether declining or experiencing improvement. The higher the CSI, food security tends to decrease (Maxwell \& Caldwell, 2008). Coping Strategies Index calculations are carried out for each season both El Niño and La Niña. Second, we determine food security position of each respondent based on studies conducted by Maxwell et al. (2013) which divided respondents into three categories, namely food security, food mild insecurity and moderate food insecurity/heavy. An analysis to determine the category of food security using the K-Mean Cluster (Ziaei, Shirani, Eshraghi, \&Keramatzadeh, 2013). Third, after assessing the classification of food security, prone to mild food and moderate/severe food insecurity, it will be determined the dynamics of food security between times.

The dynamics of food security between times is the result of taking food security conditions between time, namely food security when El Niño and La Niña occur. There are four categories of food security, category 1, that is food security at all times for households that experience food security in two seasons. Category 2 for households that experience improved food security. Category 3 is households that experience a decrease in food security, and category 4 is food insecurity all the time where families experience food insecurity in both seasons. The division of categories is based on the method used by Demeke et al. (2011) and Van Edig and Schwarze (2011).

Explanatory variables include financial assets in the form of income, ownership of savings, and ownership of credits. In addition, other livelihood assets also included in the model, namely human capital in the form of household head's age, 
work of household head and household size; natural capital, namely ownership of agricultural land; physical capital distance to the nearest market and social capital which measure with the amount of membership in the organization.

The analytical tools used are K-mean cluster, frequency distribution and Multinomial Logit regression (MNL). The Kmean cluster analysis tool to determine the position of household food security is very poor in each season. Frequency distribution to see changes in resilience status of very poor households between seasons. Furthermore, logit multinomial logit used to examine the effect of financial assets and other assets on the dynamics of food security.

\section{RESULTS}

Table 1 shows the position of food security which divided into three clusters, namely food security, food insecurity and moderate/severe food insecurity. At the time of El Nino, impoverished households were dominated by the position of mild food insecurity by $58.9 \%$, then those with food resistant positions reached $36.4 \%$. The rest of the households that have a moderate/severe food insecurity position are $4.7 \%$. Similar with the conditions when La Nina, the household was dominated by mild food insecurity (62.6\%) then followed by food security (35.5\%) and the last position was moderate/severe food insecurity $(1.9 \%)$. This finding shows that there is no significant change in food security position in both seasons. Impoverished households are still dominated by mild food insecurity conditions.

Table 1. Distribution of Respondents According to Inter-Time Food Security in Kalibawang District

\begin{tabular}{|l|c|c|c|c|}
\hline \multirow{2}{*}{ Food Security Conditions } & \multicolumn{2}{|c|}{ El Nino } & \multicolumn{2}{c|}{ La Nińa } \\
\cline { 2 - 5 } & $\mathrm{f}$ & $(\%)$ & $\mathrm{f}$ & $(\%)$ \\
\hline Hold Food & 39 & 36.4 & 38 & 35.5 \\
\hline Mild Food Prone & 63 & 58.9 & 67 & 62.6 \\
\hline $\begin{array}{l}\text { Moderate / severe food } \\
\text { insecurity }\end{array}$ & 5 & 4.7 & 2 & 19.0 \\
\hline Total & 107 & 100.0 & 107 & 100.0 \\
\hline
\end{tabular}

Source: Yuniarti, 2018

Table 2 describes in more detail the changes in the status of inter-season food security in Kalibawang District. There are two significant parts of respondents, namely households that did not change in both seasons and households experienced changes. In general, households that did not change were $61.7 \%$, while those that experienced a change were $38.3 \%$. It shows that the position of food security dominated by positions that have not changed. Impoverished households that did not change included food security in both seasons at $30.3 \%$ and mild food insecurity (69.7\%). This finding shows that for the category of food security and mild vulnerability is relatively stable in both seasons.

Households that experienced a change consisted of two parts, namely those that experienced improved food security status and experienced a decline in food security. Households that experienced an improvement in food security were 19.6\%, including mild food insecurity into food security (76.2\%), moderate food insecurity to mild food insecurity (14.3\%), and food insecurity being food resistant $(9.5 \%)$. This finding shows that change dominated by households that experience mild food insecurity. Furthermore, for households that experienced a general decline in food security status by $18.7 \%$ consisting of food security to mild food insecurity (90.0\%), food security to moderate / severe food insecurity (5.0\%), and mild food insecurity to moderate food insecurity $(5.0 \%)$. The proportion of households that experienced improvement or decline dominated by mild food insecurity. It shows that households that experience mild food insecurity are very sensitive to experience changes, both of experiencing enhancements and experiencing a decline.

Table 2. Household Distribution Based on the Dynamics of Food Security between two times

\begin{tabular}{|c|c|c|c|c|}
\hline Change & Position & $\mathbf{f}$ & $\begin{array}{l}\text { The Proportion } \\
\text { of Amount (\%) }\end{array}$ & $\begin{array}{c}\text { Total Percentage } \\
(\%)\end{array}$ \\
\hline \multirow{3}{*}{$\begin{array}{l}\text { Not Changing } \\
\text { Status }\end{array}$} & Food security & 20 & 30.3 & \multirow{3}{*}{61.7} \\
\hline & Mild food insecurity & 46 & 69.7 & \\
\hline & Medium / severe food insecurity & 0 & 0,0 & \\
\hline \multirow{3}{*}{ Repairing } & Prone to mild food to food security & 16 & 76.2 & \multirow{3}{*}{19.6} \\
\hline & $\begin{array}{l}\text { Food insecurity is in the mild of } \\
\text { food insecurity }\end{array}$ & 3 & 14.3 & \\
\hline & $\begin{array}{l}\text { Food insecurity is being food } \\
\text { resistant }\end{array}$ & 2 & 9.5 & \\
\hline \multirow{3}{*}{ Decreasing } & Hold food to mild food insecurity & 18 & 90.0 & \multirow{3}{*}{18.7} \\
\hline & $\begin{array}{l}\text { Hold food to moderate food } \\
\text { insecurity }\end{array}$ & 1 & 5.0 & \\
\hline & $\begin{array}{l}\text { Prone to mild food to moderate food } \\
\text { insecurity }\end{array}$ & 1 & 5.0 & \\
\hline
\end{tabular}


Source: Yuniarti, 2018

We use multinomial logit to examine the determinants of food security. The test includes three stages, first seeing whether all independent variables can be used together to form a model or not. In Table 3 shows the value of -LL (Log Likelihood) only with intercepts only is 278,521 , while the amount by entering the independent variable has decreased to 240,257 , or a decrease in Chi-square of 38,264 and significant at p-value 0,002. These results indicate that models with independent variables provide better accuracy for predicting the dynamics of food security than those that do not include independent variables.

Moreover, we will test the model whether the model is fit or not with the data. Deviance values indicate that Chi-square has a probability of 0.999 greater than $5 \%$. It means that the Chi-square value is not significant. This finding shows that the model is fit with empirical data. To see how much variation of the dependent variable is affected by the independent variable, we use the Pseudo R2. This value shows the variety of the dependent variable dynamics of food security that can be explained by all independent variables. Nagelkerke values explain the variation of the model by 0.327 indicate that $32.7 \%$ of the variation in the dynamics of food security can be explained by independent variables, while other variables outside the model explain $67.3 \%$.

Table 3 presents the results of multinomial logit regression analysis consisting of 3 categories, which are food security all the time, experience improvement, and experience a decrease in food security position with the reference category of food insecurity over time. Based on the results multinomial logit model 1, variable that can predict the position of food security over time are financial capital namely ownership of savings and credit ownership. Other influential assets are human capital, the age of the family head and the number of families.

Table 3: Multinomial Logit Result

\begin{tabular}{|c|c|c|c|c|c|c|c|c|c|}
\hline \multirow{2}{*}{ Variable } & \multicolumn{3}{|c|}{$\begin{array}{l}\text { Always Food } \\
\text { Secure }\end{array}$} & \multicolumn{3}{|c|}{$\begin{array}{l}\text { Has Improved } \\
\text { Food Security }\end{array}$} & \multicolumn{3}{|c|}{$\begin{array}{c}\text { Has Decreased Food } \\
\text { Security }\end{array}$} \\
\hline & Coef & Wald & $\begin{array}{l}\text { Odds } \\
\text { ratio }\end{array}$ & Coef. & Wald & $\begin{array}{l}\text { Odds } \\
\text { ratio }\end{array}$ & Coef. & Wald & $\begin{array}{l}\text { Odds } \\
\text { ratio }\end{array}$ \\
\hline Constant & 3,910 & 3,048 & & $-5,563$ & 5,044 & & $-2,401$ & 1,181 & \\
\hline $\begin{array}{l}\text { Household Head is farmer } \\
(\text { Yes = 1) }\end{array}$ & $-0,645$ & 1.006 & 0.525 & 0.365 & 0.373 & 1,440 & -0.257 & 0.177 & 0.773 \\
\hline Age of household & -0.073 & $4,764 *$ & 0.930 & 0.055 & 1,657 & 1,057 & 0.023 & 0.326 & 1,023 \\
\hline Household size & -0.542 & $3,248 * *$ & 0.581 & 0.312 & 1,889 & 1,366 & 0.151 & 0.433 & 1,163 \\
\hline $\begin{array}{l}\text { Household own saving } \\
(\text { Yes }=1)\end{array}$ & 1,220 & $2,938 * *$ & 3,387 & 0.462 & 0.559 & 1,587 & -0.441 & 0.527 & 0.644 \\
\hline $\begin{array}{l}\text { Household own credit } \\
(\text { Yes = 1) }\end{array}$ & 2,877 & $5,323 *$ & 17,764 & 1,133 & 0.760 & 3,105 & 2,246 & $\begin{array}{r}3,549 \\
* *\end{array}$ & 9,454 \\
\hline Income & 0,000 & 0.132 & 1,000 & 0,000 & 1,473 & 0.225 & 0,000 & 0.337 & 0.562 \\
\hline Distance & 0,000 & 0.534 & 1,000 & 0,000 & 1,473 & 1,000 & 0,000 & 0,000 & 1,000 \\
\hline $\begin{array}{l}\text { Household own land (Yes } \\
=1 \text { ) }\end{array}$ & -0.383 & 0.318 & 0.682 & 1,198 & $\begin{array}{r}3,040 \\
* *\end{array}$ & 3,312 & -0.009 & 0,000 & 0.991 \\
\hline $\begin{array}{l}\text { Number of organisations } \\
\text { the household } \\
\text { is member of }\end{array}$ & 0.061 & 0.066 & 1,063 & -0.92 & 0.146 & 0.912 & -0.68 & 0.089 & 0.935 \\
\hline $\begin{array}{l}\text { Number of observation } \\
-2 \text { Log Likelihood interce } \\
-2 \text { Final Log Likelihood } \\
\text { Deviance } \\
\text { Nagelkerke }\end{array}$ & & $\begin{array}{l}107 \\
278.521 \\
240.257 \\
0.981 \\
0.327\end{array}$ & & & & & & & \\
\hline
\end{tabular}

Note : * Significant at $5 \%$;* significant at $10 \%$.

\section{Source :Yuniarti, 2018}

Savings ownership has an odds ratio greater than one indicating that households that have savings have a higher probability of food security than households without savings ownership. It is because savings can be a reserve that can be used at any time by the household. According to Guo (2011), savings are the most stable determinant of food security when an economic crisis or shock occurs. Furthermore, financial savings capital can maintain household liquidity when facing vulnerabilities. Households in Kalibawang sub-district that have savings at El Nińo are 42.1\%, the remaining 57.2\% do not have savings. At the time of La Nińa, savings ownership decreased to $28.0 \%$, while those that did not have $72.0 \%$. It means that there are changes in ownership of savings in two seasons.

Moreover, the similar finding suggested by credit ownership which significantly affects food security where the odds ratio is more than 1 . This variable is one of the factors capable of supporting food security. This finding is consistent with the 
study conducted by Asenso-Okyere et al. (2013) and Dzanja et al. (2013). This finding supported by empirical studies that show that buying food with debt is one of the coping strategies chosen by households in the face of limited income and food (Cordero-Ahiman, Santellano-Estrada, \&Garrido, 2018; Gupta, Singh, Seth, Agarwal, \&Mathur, 2015; Ziaei et al., 2013; Tanziha\&Ariani, 2010).

Households that had a credit when El Nińo were $88.8 \%$. When La Nińa households that have credits have decreased to $76.6 \%$, so those who do not have credits are $23.4 \%$. The number of households that have credits when El Nińo is more than in La Nińa. But in general, the majority of households have credits in both seasons. The most significant sources of credits come from social institutions or organizations which followed by households such as cooperatives, relatives, bank, and neighbors.

The age of the head of the family has an odds ratio of less than one indicating that households with older heads of household have a smaller probability of being able to withstand food at all times than those with younger heads of age. Likewise, the number of families has an odds ratio of less than 1, households that have more families have a lower probability of holding food at all times. A large number of families will cause greater fulfilment of food needs. This finding is in line with the studies of Sekhampu (2013), Demeke et al. (2011), Purwaningsih et al. (2010), Radha and Prasanna (2010), and $\mathrm{Li}$ and $\mathrm{Yu}$ (2010). The survey results show that the average number of families in Kalibawang District is five people, consisting of two adults and three children. When viewed from the composition of families that are still dominated by children, it suggests that the number of families still gives more burden to fulfil food security, so that it will reduce the possibility of households to hold food.

Model logit 2 shows that the critical asset is natural capital, namely ownership of agricultural land. The odds ratio of land ownership greater than 1 indicates that households that have agrarian land have a probability of experiencing improved food security than those without agrarian land. This condition because households that have agricultural land have the potential to increase resilience by producing their food. Empirical studies that support this relationship involved Amwata et al. (2016), Osayande and Ada-Okungbowa (2014), Ejaz et al. (2012) and Li and Yu (2010)

Model logit 3 describes the category of households that experience a decrease in food security by reference to food insecurity at all times. A significant factor in this model is credit ownership. Household that has credit will has higher probability to experience decline position. Credits have a particular effect because they affect two categories, namely households that are food resistant all the time and experience a decline. On the one hand, ownership of a credit can affect food-resistant households at all times. It may be due to the security being used to buy food. But the opposite happens when the credit used for non-food needs. It will increase the burden to fulfil food. Therefore, the effect of the credit depends on the credit allocation.

The financial capital of income, the work of the head of the household, the distance to the nearest market, and social capital have not been able to predict all categories of food security. Financial capital in the form of income has no impact because households do have limitations in income. According to Guo (2011) for low-income households, income is not a determinant of the status of food security, but instead, household assets are a major determinant of household food security. Furthermore, this is made possible by the problem of revenue allocation. According to Maxwell et al. (2013), the allocation of income is not only for food but also for non-food expenditure, such as health care, and education. This finding supported by the survey that the portion of income expenditure used in Kalibawang District for food expenditure is $42.4 \%$ and non-food is $57.6 \%$.

Occupation of the household head has no effect on the dynamics of food security. This finding is consistent with the study

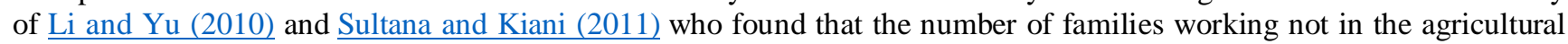
sector did not affect food security. However, this finding is not in line with the studies of Sekhampu (2013) and Amwata et al. (2016). Income from agriculture is not sufficient to fulfil food security. This finding is in line with the study of Aminah (2015) who found that the characteristics and capacity of small farmers are low, so their influence on food security levels is also weak. Therefore, agricultural work cannot provide adequate income for farmer households to achieve food security.

The distance to the market is not significant in predicting all categories. This finding is possible because households obtain food from the nearest retailer, not to the market so that the distance does not affect the position of food security. Social capital as measured by the amount of household membership in an organisation or community activity is not significant in predicting all categories. The findings of this social capital are consistent with the study of Demeke et al. (2011), but inconsistent with Dzanja et al. (2013) and Martin et al. (2004). Involvement in many social, religious and peasant organizations cannot predict all food security positions. These results indicate that household involvement in social activities has not provided benefits yet for household.

\section{CONCLUSION}

Based on the results, we can conclude that very poor households when facing climate change did not experience significant changes in food security positions in both seasons (El Nińo and La Nińa), where mild food insecurity still dominates impoverished households. Also, the proportion of households that experienced improvement or decline was dominated by mild food insecurity. This condition shows that households that experience mild food insecurity are very sensitive to change, both undergoing enhancements and decreasing. For that, there is a need to strengthen food security, especially in 
households that experience mild food insecurity and moderate/moderate food insecurity. Other findings indicate that financial assets that can support food security over time are ownership of savings and credits. The unique position is shown by credit that have two sides, namely increasing the probability all the time, but on the other hand, can also increase the probability of a decrease in food security. Therefore, it is necessary to strengthen financial institutions for poor households to support food security both savings and credit. Strengthening existing institutions around homes can be an option to enhance food security. Strengthening financial institutions expected to be able to make financial institutions more organized, so poor household can make it as a buffer when face vulnerability.

\section{ACKNOWLEDGEMENT}

The authors are appreciative to all households who participated in the interviews. Furthemore, we would like to thank all of enumerator for their contribution to the fieldwork. This study had been funded by the LPPM of Universitas Ahmad Dahlan.

\section{REFERENCES}

1. Akinboade, O. A., Mokwena, M. P., \&Adeyefa, S. A. (2016). Determinants of Food Insecurity among the Urban Poor in the City of Tshwane, South Africa. Journal of Economics and Development Studies, 4(2), 101-114. http://doi.org/10.15640/jeds.v4n2a9

2. Aminah, S. (2015). PengambanganKapasitasPetani Kecil LahanKeringUntukMewujudkanKetahananPangan (Improving and Dry Farmer Capacity Toward Adequate Food Security. JurnalBinaPraja, 7(3), 197-210.

3. Amwata, D. A., Nyariki, D. M., \&Musimba, N. R. K. (2016). Factors Influencing Pastoral and Agro Pastoral Household Vulnerability to Food Insecurity in TheDryland of Kenya: A Case Study of Kajiado and Makueni Counties. Journal of International Development, 787, 771-787. https://doi.org/10.1002/jid

4. Asenso-Okyere, K., Mekonnen, D. A., \&Zerfu, E. (2013). Determinants of food security in selected agro-pastoral communities of Somali and Oromia Regions, Ethiopia. Journal of Food Science and Engineering, 3(9), 453.

5. Butt, M. S., \&Iram, U. (2004). Determinants of household food security: An empirical analysis for Pakistan. International Journal of Social Economics, 31(8), 753-766. https://doi.org/10.1108/03068290410546011

6. Chang, Y., Chatterjee, S., \& Kim, J. (2014). Household Finance and Food Insecurity. Journal of Family and Economic Issues, 35(4), 499-515. http://doi.org/10.1007/s10834-013-9382-z

7. Cordero-Ahiman, O. V., Santellano-Estrada, E., \&Garrido, A. (2018). Food access and coping strategies adopted by households to fight hunger among indigenous communities of Sierra Tarahumara in Mexico. Sustainability (Switzerland), 10(2), 1-14. http://doi.org/10.3390/su10020473

8. Demeke, A. B., Keil, A., \& Zeller, M. (2011). Using panel data to estimate the effect of rainfall shocks on smallholders food security and vulnerability in rural Ethiopia. Climatic Change, 108(1), 185-206. http://doi.org/10.1007/s10584-010-9994-3

9. Dzanja, J. L., Christie, M., Fazey, I., \& Hyde, A. G. (2013). The role of social capital on rural food security: the case study of Dowa and Lilongwe Districts in Central Malawi. Access International Journal of Agricultural Sciences, 1(4), 46-56. Retrieved from https://pure.aber.ac.uk/portal/en/publications/the-role-of-social-capital-on-rural-food-securitythe-case-study-of-dowa-and-lilongwe-districts-in-central-malawi(b4ef8639-d040-4864-80a5-eeebf477970e).html

10. Economist Intelligence Unit. (2012). Global food security index. Retrieved from http://foodsecurityindex.eiu.com/

11. Ejaz, R., Khan, A., Azid, T., \&Tosee, M. U. (2012). Determinants of food security in rural areas of Pakistan. International Journal of Social Economic, 39(12), 951-964. http://doi.org/10.1108/03068291211269082

12. Gitz, V., Meybeck, A., Lipper, L., Young, C. De, \&Braatz, S. (2016). Climate change and food security: risks and responses. Food and Agriculture Organization of the United Nations (FAO) Report, 110.

13. Gregory, P. J., Ingram, J. S., \&Brklacich, M. (2005). Climate change and food security. Philosophical Transactions of the Royal Society B: Biological Sciences, 360(1463), 2139-2148. http://doi.org/10.1098/rstb.2005.1745

14. Guo, B. (2011). Household Assets and Food Security: Evidence from the Survey of Program Dynamics. Journal of Family and Economic Issues, 32(1), 98-110. http://doi.org/10.1007/s10834-010-9194-3

15. Gupta, P., Singh, K., Seth, V., Agarwal, S., \&Mathur, P. (2015). Coping Strategies Adopted by Households to Prevent Food Insecurity in Urban Slums of Delhi, India. Journal of Food Security, 3(1), 6-10. http://doi.org/10.12691/jfs-3-1$\underline{2}$

16. KulonProgo Regency Regional Government. (2016). RencanaKerjaPemerintah Daerah KabupatenKulonProgo (KulonProgo Regency Regional Government Plan). Wates.

17. Li, Y., \& Yu, W. (2010). Households Food Security in Poverty-Stricken Regions: Evidence from Western Rural China. Agriculture and Agricultural Science Procedia, 1, 386-395. http://doi.org/10.1016/j.aaspro.2010.09.048

18. Martin, K. S., Rogers, B. L., Cook, J. T., \& Joseph, H. M. (2004). Social capital is associated with decreased risk of hunger \$. Social Science \& Medicine 58, 58, 2645-2654. http://doi.org/10.1016/j.socscimed.2003.09.026

19. Maxwell, D., Coates, J., \&Vaitla, B. (2013). How Do Different Indicators of Household Food Security Compare? Empirical Evidence from Tigray. Feinstein International Center, Tufts University: Medford, USA.

20. Maxwell, D. G., \& Caldwell, R. (2008). The Coping Strategies Index Field Methods Manual Second Edition. Feinstein International Center.

21. Misselhorn, A. A. (2005). What drives food insecurity in southern Africa? a meta-analysis of household economy studies. Global Environmental Change, 15(1), 33-43. http://doi.org/10.1016/j.gloenvcha.2004.11.003

22. Muche, M., \&Tadele, E. (2015). Analysis of Household Level Determinants of Food Security in JimmaZone , 
Ethiopia. Journal of Economics and Sustainable Development, 6(9).

23. Osayande, I., \& Ada-Okungbowa, C. (2014). Determinants of Food Security Status of Yam-Based Farmers in Orhionmwon Local Government Area of Edo State , Nigeria. International Journal of Agriculture Innovations and Research, 3(1), 281-286.

24. Purwaningsih, Y., Hartono, S., \&Mulyo, J. H. (2010). AnalisisPermintaanPanganRumahTanggaMenurut Tingkat KetahananPangan di ProvinsiJawa Tengah (Analisis Data Susenas 2008) (The Analysis of Household Food Demand on Central Java Province) (Analysis of Susenass Data 2008). EKO-REGIONAL, 5(1), 43-52.

25. Quisumbing, A. R., \&Meinzen-Dick, R. S. (2001). Empowering Women to Achieve Food Security. Focus, 1(2).

26. Rachman, H. P. S. (2004). Identifikasi Wilayah RawanPangan di Propinsi Daerah Istimewa Yogyakarta [Identification of Food Prone Areas in Special Region of Yogyakarta ]. ICASERD Working Paper No.36, (36).

27. Radha, V., \&Prasanna, N. (2010). Household entitlements and food security: SEN's approach - a reality. Interdisciplinary Journals of Contemporary Research in Business, 2(2), 306-320.

28. Sekhampu, T. (2013). Determination Of The Factors Affecting The Food Security Status Of Households In Bophelong, South Africa. International Business \& Economics Research Journal-May, 12(5). Retrieved from https://repository.nwu.ac.za/bitstream/handle/10394/11271/Sekhampu_Determination of the factors affecting the food security.pdf?sequence=1\&isAllowed=y

29. Shahid, A., \& Siddiqi, M. W. (2010). Food Security Analysis of Pakistan: Time Series Approach. Interdisciplinary Journal of Contemporary Research in Business, 2(2008), 288-307.

30. Sharaunga, S., Mudhara, M., \&Bogale, A. (2016). Effects of ' women empowerment' on household food security in rural KwaZulu-Natal province. Development Policy Review, 34(2), 223-252.

31. Smith, L. D. (1997). Price stabilization, liberalization and food security: conflicts and resolutions? Food Policy, 22(5), 379-392. https://doi.org/10.1016/S0306-9192(97)00029-8

32. Sultana, A., \&Kiani, A. (2011). Determinants of food security at household level in. African Journal of Business Management, 5(34), 12972-12979. https://doi.org/10.5897/AJBM11.1441

33. Tanziha, I., \&Ariani, M. (2010). DeterminanIntensitasKerawananPangansertaHubunganyaDengan Food Coping Strategies (Food Insecurity Determinan and The Relation with Food Coping Strategies). JurnalGizi Dan Pangan, $5(51), 39-48$.

34. The World Bank Group. (2011). Vulnerability, Risk Reduction, and Adaptation to Climate Change, Sri Lanka. Climate Risk and Adaptation Country Profile April 2011. Washington.

35. Van Edig, X., \&Schwarze, S. (2011). Short-term poverty dynamics of rural households: Evidence from Central Sulawesi, Indonesia. Journal of Agriculture and Rural Development in the Tropics and Subtropics, 112(2), 141-155.

36. Wheeler, T., \& von Braun, J. (2013). Climate change impacts on global food security. Science, 341, $508-513$. https://doi.org/10.11261239402

37. Ziaei, M., Shirani, F., Eshraghi, F., \&Keramatzadeh, A. (2013). Food Security and Coping Strategies Case Study of Rural Areas of Gorgan. International Journal of Agriculture and Crop Science, 6(4), 225-231.

38. Ziervogel, G., \&Ericksen, P. J. (2010). Adapting to climate change to sustain food security. WIREs Climate Change, Volume 1, 525-540. https://doi.org/10.1002/wcc.56 